\title{
Examining the Link among Agility, Knowledge Management Practices and Firm Performance: Empirical Evidence from Electrical and Electronics Manufacturing Firms
} \author{
Empirikal daripada Syarikat Perkilangan Elektrik dan Elektronik di Malaysia) \\ Eu Chin Ong \\ Cheng Ling Tan \\ (Graduate School of Business, Universiti Sains Malaysia)
}

(Kajian berkaitan Perhubungan Ketangkasan, Amalan Pengurusan Pengetahuan dan Prestasi Firma: Bukti

\section{ABSTRACT}

The study empirically investigates the relationship between agility and knowledge management practices on firm performance among the electrical and electronics manufacturing firms in Malaysia. The study was conducted using a survey method. A total of 85 manufacturing firms participated in this study. The findings showed that knowledge management practices mediate the relationship between agility and firm performance, which is in line with the Knowledge-Based View (KBV) where knowledge is an asset of the firm. The findings also empirically support the theoretical conceptualization of agility as co-dependent on knowledge management. The implications for practising managers within manufacturing firms are twofold, where agility alone does not lead to increased firm performance, and the implementation of only one of the factors is suboptimal.

Keywords: Agility; knowledge management practices; firm performance; manufacturing; productivity

ABSTRAK

Kajian ini menyelidik perhubungan antara ketangkasan dan pengurusan pengetahuan terhadap prestasi syarikat secara empirikal di kalangan syarikat perkilangan elektrik dan elektronik di Malaysia. Kajian ini dijalani melalui tinjauan survei, dan menerima 85 respons dari kalangan syarikat perkilangan. Hasil kajian menunjukkan bahawa amalan pengurusan pengetahuan mengantarai hubungan antara ketangkasan dan prestasi syarikat, yang sejajar dengan teori Pandangan Berasaskan Pengetahuan (Knowledge Based View - KBV), di mana pengetahuan adalah sesuatu aset syarikat. Penemuan empirikal ini menyokong konsep berpandukan teori, iaitu ketangkasan bergantung kepada pengurusan pengetahuan. Implikasi untuk mempraktikkan pengurus dalam syarikat perkilangan adalah dua ganda, iaitu ketangkasan dilaksanakan secara sendirian sahaja tidak menyebabkan peningkatan prestasi syarikat, dan hanya salah satu faktor yang dilaksanakan adalah tidak optimum.

Kata kunci: Ketangkasan; amalan pengurusan pengetahuan; prestasi syarikat; perkilangan; produktiviti

\section{INTRODUCTION}

The business world of today is challenging. With the rapid product lifecycle turnover, unceasing competition, and an uncertain business climate driving effort by governments, the private sector, and educational institutions are urged to develop future growth strategies (Cavusgil \& Knight 2015; Shipham 2011). The challenges for companies in Asia are even more complicated, with problems of economic trade war uncertainties, severe competition, and a changing political environment, adding to the challenges of developing into advanced economies (Özer 2020). These mentioned challenges must also include the unforeseen risks associated with the unprecedented disruption of business in 2020 due to the COVID-19 viral disease pandemic worldwide (World Health Organization 2020), which has been predicted to affect 5 million businesses (Dun \& Bradstreet 2020).
Looking beyond the immediate business challenges, and towards the longer-term post COVID-19 recovery and business sustainability, is just as important. Of high importance to attain the goal of sustained growth is the need to increase productivity in companies in the developing world (Janipha \& Ismail 2013). The uncertainties in the global market and the decline of competitiveness, it is consequently recommended that Malaysian manufacturers to take proactive actions to manage their resources effectively and efficiently (Tan et al. 2018). Major world organizations have also made reports on the status of Malaysian manufacturing sector performance, which has shown comparably slower growth behind the neighboring countries (World Bank Group 2016). To overcome these challenges, the Malaysian Government has also initiated efforts to increase economic output and per capita productivity by supporting local industry development, particularly 
to the critical sectors such as Electrical \& Electronics (E\&E), through direct knowledge transfer via training and technical programs which include knowledge sharing, rapid and flexible coordination tactics (SME Corporation Malaysia 2012).

This view of low productivity was developing knowledge capabilities in workers is supported by reports specifically looking into E\&E manufacturing firm by the International Labor Organization / ILO (2014). that the significant challenges of productivity increases were employee knowledge and customer response production agility. The challenges were implied as insufficient employee knowledge practices being influenced by the factor of companies' responses to business agility needs, which was through the usage of temporary workers who were less incentivized to contribute to business sustainability. The findings concur with Janipha and Ismail (2013) study, where insufficient knowledge in technology systems distinguishes developing countries companies and foreign companies (Ng \& Jantan 2010), which applies to the current state of manufacturers in Malaysia. In short, a robust knowledge culture through supportive practices of the management of knowledge enables innovative and agile production, which in turn increases productivity in E\&E manufacturing firms (Buenechea-Elberdin et al. 2017; ILO 2014).

This reasoning of knowledge management and agility has been recently conceptualized in literature as key factors, which synergistically lead to the increased operational excellence component measures of firm performance (Carvalho et al. 2019). This understanding of the correlation of the factors of Agility and Knowledge Management in relation to measures of firm performance is of great interest for business performance researchers and also is supportive of government policies to aid Malaysian manufacturers.

However, there has been sparse empirical research to date of a model based on the proposed relationships of these factors, and proposes the study of the research problem is to determine if Agility and Knowledge Management Practice increase Firm Performance for E\&E manufacturers in Malaysia. This study aims to contribute empirically by studying the conceptual model of agility and knowledge management practices concerning firm performance, within the context of Malaysian E\&E manufacturing firms.

\section{LITERATURE REVIEW}

\section{FIRM PERFORMANCE}

Contemporary performance measurement is implemented to monitor and control organizational performance and is the practices of measuring job outcomes, precisely output and accomplishment (Harbour 2007; Nanni et al. 1992). A study by Bakar and Ahmad (2010) summarized the general performance measures in research use today as physical, reputational, organizational, financial, human intellectual, and technological. Of these, organizational measures are relevant to the context of companies in the business of manufacture. Research in the literature of common operational measures shows operational measures consisting of customer satisfaction, employee morale, productivity defects and quality to most closely track firm practices in previous studies (Ahire et al. 1996; Dow et al. 1999; Rahman \& Bullock 2002; Samson \& Terziovsky 1999).

In terms of research involving manufacturing companies, the specific measures used are mainly of operational measures such as - waste reduction (Dubey \& Gunasekaran 2015), product quality (Ahire \& O'Shaughnessy 1998), customer delivery, and productivity (Cegarra-Navarro et al. 2016). These identified elements exist in a concise measurement set from Kaynak (2003), which is a composite measure, comprised of productivity, quality, cost, and delivery. This was found to be particularly relevant to manufacturing companies and is selected as the output item measures in this study.

\section{AGILITY}

Agility is a systemic ability of the firm to operate and cope with business disturbances to survive and thrive by seizing opportunities out of the crisis (Dahlgaard \& Dahlgaard 2006; Zhang \& Sharifi 2007). Agility is defined as agile capabilities; interchangeable terms were used in literature which refers to structures of organization agility, such as "adaptability", "flexibility", and "responsiveness" (Almahamid et al. 2010; Sharifi \& Zhang 2000). Put another way, an agile organization structures internal process and systems to shift products and supply lines to respond in real-time to changing customer demand (Youssef 1994). This is critical, as agility within organizations assures a sustainable growth business during uncertain times (Ong et al. 2019).

The need for agility was driven by the contemporary business environment, which has evolved from one of a clear and relatively straightforward trajectory, into that of short product life cycles, fast technology updates, rapid organization direction changes, and impatient customers (Zhang et al. 2003). Manufacturing companies evolved the desirable organization capability of responsiveness to organize order sizes flexibly and shipping delivery modes in response to rapidly changing market needs (Carvalho et al. 2012; Zhang \& Sharifi 2007). These capabilities meet the two critical criteria defining agility in an organization (Carvalho et al. 2012; Reichhart \& Holweg 2007), namely flexibility with supplier incoming and customer outgoing practices.

The ability to enable business processes to take account for new opportunities, and to structure supplier orders and adjust customer delivery schedules and methods, is found in literature, as the ability of firms to reorganize operations and processes needed to raise 
firm performance (Zhang 2011). Literature showed a direct relationship between agility practices and firm performance (Inman et al. 2011; Swafford et al. 2008) or as an indirect enabler for various performance measures within firms (Carvalho et al. 2012; Yusr et al. 2017). Agility has also been theorized and measured as an outcome and demonstrated applicability across sectors and industries (Yauch 2011; Zhang 2011).

Empirical studies in supply chain agility with emphasis on responsiveness to threats or opportunities, supply chains flexibility, and pro-activeness in decision making, have shown a link with measures of firm performance, such as Return on Assets (Gligor et al. 2015), and organizational performance (Almahamid et al. 2010). A more pertinent supporting study with Agility measures (Inman et al. 2011; Sharifi \& Zhang 2001) of manufacturing firms, shows a strong relationship between the measures of flexibility, process management, knowledge management, and the firm's operational performance. Conclusively, the literature indicated that agility has a direct and indirect influence on firm performance. Therefore, agility as a capability related to existing firm performance relationship models as theorized by Carvalho et al. (2019) is supported, and as a primary factor to formulate the first hypothesis as below.

\section{$\mathrm{H}_{1} \quad$ Agility leads to increased firm performance}

\section{KNOWLEDGE MANAGEMENT}

Knowledge is the cumulative information which has been attained from experience by individuals, which can also be termed as 'justified true belief' (Nonaka \& von Krogh 2009). The value of accumulated knowledge only becomes apparent with the cohesive systemic utilization of the knowledge resource, as was shown in a study of individuals in an organization (Huang 2009). For individuals, knowledge is a fluid mix of framed experiences, values, contextual information, and expert insight that provides a framework for evaluating and incorporating new experiences and information (Yee et al. 2019). To organizations, knowledge is viewed as an intangible resource which brings competitive advantages as resources which can be utilized to achieve organization objectives (Darroch 2003).

Knowledge management is the explicit processes, techniques and capabilities to manage knowledge as company resources and assets which are documentable, storable, and transmissible (Davenport 1996; Nonaka et al. 1996; Wiig 1997). This view is in line with the Resource-Based View (RBV) of the firm (Barney 1991; Wernerfelt 1984), which posits that resources are utilized to the advantage of a firm. This perspective of knowledge as a resource has been expanded into a separate theory of the Knowledge-Based View (KBV) as a complement to RBV. KBV theory posits that higher organizational performance can be attained with the systemic utilization of available knowledge resources through knowledge management (Grant 1996; Kogut \& Zander 1992). Knowledge management is essential in an organization as it captures, distributes and effectively applies both tacit and explicit knowledge (Yee et al. 2020).

The utilization of knowledge management enables organizations to enhance employees' effectiveness, which leads to a performance increase in all sizes of firms (Knight \& Howes 2003). This has led to an interest in knowledge management growing within organizations looking to gain advantages over competitors (Darroch 2003; Darroch 2005; Davenport \& Klahr 1998; Knight $\&$ Howes 2003). Awareness for the need of knowledge management has reached developing nations governments and private companies of all sizes, such as in Malaysia, where interest has grown for enhancing utilization of knowledge management (Hamzah \& Woods 2004). More recent studies of Malaysian SMEs (Ling \& Shan 2010) showed that various sectors in SMEs aware of the benefits of knowledge management, and have attempted varying levels of implementation, but have not yet fully exploited its entire interest. This is due to a deficient understanding of knowledge management component interactions, and its attendant practicality of implementation, which the literature next seeks to clarify.

Knowledge management literature shows different terminologies and adaptations, where models in use for knowledge management process studies utilize variable measures, such as by Darroch (2003) and Gold etal.(2001). Studies where the components of knowledge processing capability (Gold et al. 2001) or the three components of acquisition, conversion and application model (Darroch 2003) are still analyzed today as indicators of knowledge management to performance (Yusr et al. 2017). Studies utilizing component models can impact the strength of relationships when broad predictor dimensions are related to narrow operational performance measures (Yusr et al. 2017), such as operational productivity or quality. This has led to inconclusive results when relating studies to operational performance or financial-based performance (Darroch 2005), and the approach narrows the scope by which measures of knowledge management related to organizational performance. To resolve this, more recent developments of measures have linked actual performance of organizations items with a single knowledge management variable composed of elements of all three components of knowledge management, termed knowledge management practices (Zack et al. 2009).

Knowledge management practices studies have been found to be positively associated with organizational performance as demonstrated in various literature of knowledge management, both qualitatively and quantitatively (Darroch \& McNaughton 2003; Davenport \& Prusak 1998; Zack et al. 2009). It was also found in a recent review of empirical research into knowledge management practices orientation, that various measures of knowledge management practices are positively 
related to strategic organizational performance (Hussinki et al. 2017). While these are general measures of performance within organizations, it is the specific component measures of organizational performance which play a more critical role in relation to knowledge management practices.

In a study of knowledge management usage and influence on organizations, Khalifa et al. (2008) found that knowledge management systems in practices was a predictor for measures of organizational performance in terms of profitability, customer responsiveness, and supply chain efficiency. In a similar vein, Tan and Wong (2015) showed that constructs of knowledge management factors, knowledge management processes and knowledge resources are inter-correlated, and have a strong relationship with manufacturing performance. This indicates that certain measures are of higher importance to researchers, and calls for a relevant measure which encompasses key knowledge management practices which are predictors of organizational performance.

In assessing the relationship between knowledge management and organizational performance, Zack et al. (2009) developed and tested a new construct termed as knowledge management practices. Zack et al. (2009) developed the constructed measure based on relevant organizational practices, which was determined as the ability to locate and share existing knowledge, the ability to experiment and create new knowledge, a culture that encourages knowledge creation and sharing, and, a regard for the strategic value of knowledge and learning. This emphasis on process and cultural elements within organizational utilization of knowledge management is a development on the theory of the Knowledge-Based View of the firm, which predicts increased organizational performance.

The new construct of knowledge management practices is composed of a twelve question composite measure, which consists of four key dimensions of the strategic planning process, knowledge as benchmarked against competitors, knowledge as explicitly mapped to value creation, and a measure for the knowledge management organizational unit. The empirical study conducted by Zack etal.(2009) of knowledgemanagement practices, demonstrated a strong relationship with increased organizational performance and is, therefore, an accepted predictor of firm performance in this study.

\section{KNOWLEDGE MANAGEMENT PRACTICES} AND FIRM PERFORMANCE

Studies conducted on components of knowledge management, such as to knowledge creation and intellectual capital (Mehralian et al. 2018) to the Balanced Scorecard, and firm performance measures of profitability and market share (Bell Detienne et al. 2004; Theriou et al. 2011), have shown strong correlations. However, this does not hold true for all measures, as empirical studies conducted purely on Knowledge
Management components of acquisition, conversion and application (Darroch 2003; Darroch 2005), have shown no clear direct link with firm performance, other than to Innovation measures, and this was also shown in the context of Malaysia (Yusr 2017).

The gap was studied by Zack et al. (2009), where the literature indicated a contextual consideration for the actual usage of knowledge management in a practical sense when measuring usage within organizations. The usage of the proposed measures by Zack et al. (2009) of twelve-measure of knowledge management practices showed a significant relation to organizational performance. The study also revealed that organizational performance leads to increased financial performance, and played a mediating role between knowledge management practices and financial performance. The findings were built by Carvalho et al. (2019), where knowledge management was a vital enabler of the firm performance.

However, the gap remains that both empirical and conceptual studies (Carvalho et al. 2019; Zack et al. 2009) were not tested in the context of generalizability to other countries and that the organizations of the study were not restricted to any single sector which may have a limitation to the applicability of the concept. With the empirical research conducted only in America and Australia (Zack et al. 2009), the gap of generalizability and applicability requires a local context study to fully assess the value of knowledge management to firm performance in Malaysia, and the second hypothesis for this study addresses this shortfall. $\mathrm{H}_{2}$ Knowledge management practices is positively
related to firm performance

\section{AGILITY AND KNOWLEDGE MANAGEMENT PRACTICES}

Literature linking agility to firm performance has shown correlation under certain context (Gligor \& Holcomb 2012), but not to all measures of firm performance, such a case is for firm agility to firm financial performance (Gligor et al. 2015). The study of agility to the firm performance by Gligor et al. (2015), showed that agility did not affect firm financial performance directly, but only through the mediation of secondary factors, such as in the context of higher levels of environmental munificence, dynamism, and complexity, or in other words, when business uncertainty is more elevated. This implies that agility is a practice which requires the enablement through secondary factors, to bring direct benefits to the company bottom line, and has been suggested to be an enabling capability or asset (Gligor et al. 2015).

Findings in studies of adjacent specializations in agility have shown that Agile practices are influenced by external factors or enablers, such as resources and environmental conditions (Gligor et al. 2015). The antecedents of agility identified by Zhang and Sharifi (2000), have shown correlations from literature 
(Gunasekaran 1998; Yusuf et al. 1999), which can be summarized as a list of ten item agility enablers (Carvalho et al. 2019), the most prominent being knowledge management. These factors form the basis for the theoretical contribution of Carvalho et al. (2019), where Operational Excellence Initiatives correlate with organizational agility when enabled by knowledge management. Thus, the third hypothesis is constructed as follows.

$\mathrm{H}_{3}$ Agility is positively related to knowledge
management practices.

\section{KNOWLEDGE MANAGEMENT PRACTICES MEDIATES THE RELATIONSHIP BETWEEN AGILITY AND FIRM PERFORMANCE}

Research conducted by Gligor et al. (2015), found that agility and the dynamic capability it represents are influenced by the Resource-Based View enabler of prior knowledge as an asset inherent to the firm. The Knowledge-Based View provides an explanatory value of firm performance measures, such as operational excellence, and has also been conceptualized by Carvalho et al. (2019), where knowledge management and agility are assets and enablers of operational excellence within firms. Empirical studies of manufacturing companies have theorized that agile capabilities and the Knowledge sharing component of knowledge management has a correlated positive effect on organizational competitive advantage (Almahamid et al. 2010).

Recent empirical studies support this, where a study of random Spanish companies employing IT tools for knowledge management shows that organizational agility and knowledge application processes lead to increased firm performance (Cegarra-Navarro et al. 2016). The value of knowledge as a resource has been shown as a mediator for specific outcomes, such as innovation (Yusr et al. 2017), and operational performance (Zack et al. 2009), which implies that knowledge as an asset, enables other relationships which were previously insignificant.
Such a case is with the findings of Gligor et al. (2015) where agility is theorized as being influenced by the missing factor of knowledge, which is an important missing link to understanding how actions can benefit from derived historical results.

Here the model of the study is proposed, where agility as a predictor of firm performance is enabled by the factor of Knowledge Management Practices, which results in a consistent positive relationship. Given that Knowledge Management is shown as an enabler of relationships in various empirical studies (Mehralian et al. 2018; Yusr et al. 2017), Knowledge Management Practices will also be studied as an enabler, in the factor as a mediator of the relationship between agility and firm performance. Hence, the fourth hypothesis is determined as follows:

$\mathrm{H}_{4}$ Knowledge management practices mediate the relationship between agility and firm performance

\section{RESEARCH FRAMEWORK}

Following the operational excellence model by Carvalho et al. (2019) and the findings of Gligor et al. (2015), the interplay of the three factors can be drawn up in Figure 1.

\section{METHODOLOGY}

\section{SURVEY INSTRUMENT}

A questionnaire survey was developed to include all factors with agility (ten items), knowledge management practices (twelve items), and firm performance (five items). The questionnaire was reviewed by a panel of academic researchers and management professionals to ensure legibility, clarity, validity and relevance to the industry in question. The questionnaire comprised three sections, with respectively the first being the demographics of the organization, the second being the factors of agility and knowledge management practices,

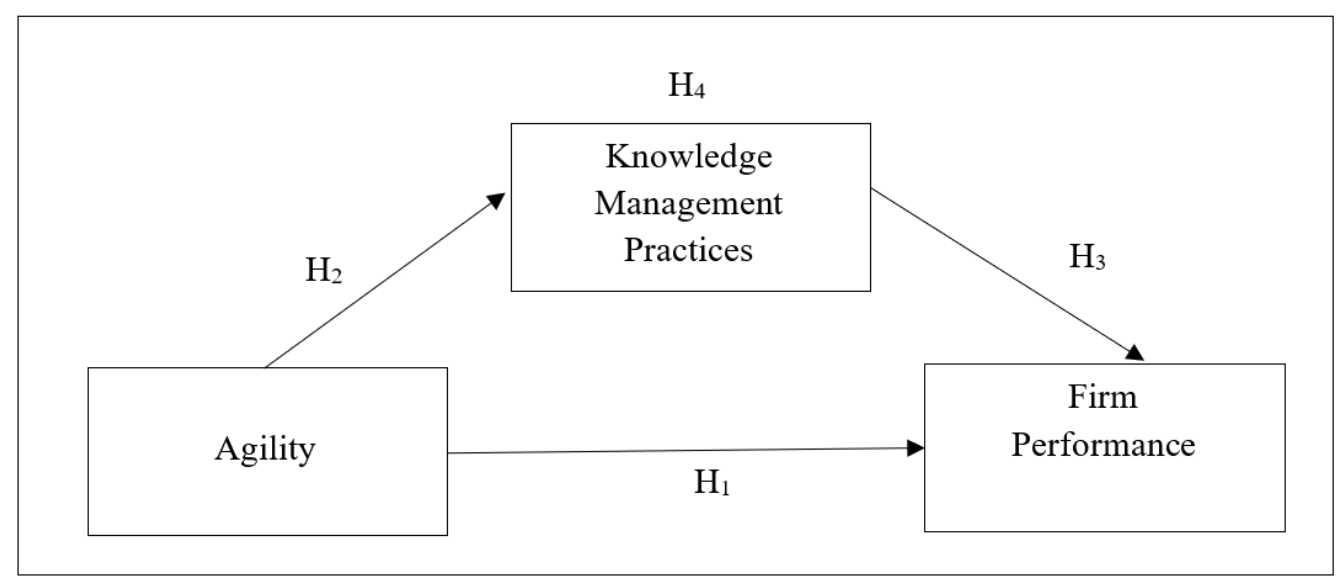

FIGURE 1. Research framework 
and last addressing the firm performance factors, respectively.

Agility items were adapted from Inman et al. (2011). There are ten items which are: the company has the capabilities necessary to detect, predict and plan for market changes; the production processes of the company are flexible in terms of product models and configurations; the company reacts immediately to implement new changes into its manufacturing processes and systems; the company has the appropriate technology and technological capabilities to quickly respond to changes in customer demand; the company's strategic vision emphasizes the need for flexibility and agility to respond to market changes; the company has formed co-operative relationships with customers and suppliers; the company's managers have the knowledge and skills necessary to manage change; the company has the capabilities to meet and exceed the levels of product quality demanded by its customers; the company has the capabilities to deliver products to customers on time and to quickly respond to changes in deliver requirements; and, the company can quickly introduce new products to market. All questions were measured using fivepoint Likert-scale to gauge the level of agreement or disagreement on each instrument. Respondents responded to the items from $1=$ "strongly disagree" to $5=$ "strongly agree" with each statement in the questionnaire.

Knowledge management practices items were adapted from Zack et al. (2009). There are twelve items measure the company: fully recognizes knowledge as important in the strategic planning exercises; compares strategic knowledge against the competitors; has developed a knowledge process that links knowledge expertise to the creation of new products and services; able to identify sources of expertise within the company; employees are valued for what they know; looks for opportunities to try new things and learn more about customers; looks for opportunities to try new things and learn more about products and services; looks for opportunities to try new things and learn more about technologies and internal operations; encourages and rewards the sharing of knowledge; has effective internal processes for transferring best practices throughout the company; utilizes external sources of knowledge, including customer knowledge effectively; and, has a knowledge management group that is a recognized source of value creation within the organization. All questions were measured using five-point Likert-scale to gauge the level of agreement or disagreement on each instrument. Respondents responded to the items from 1 $=$ "strongly disagree" to $5=$ "strongly agree" with each statement in the questionnaire.

Firm performance items were adopted from Kaynak (2003). The items are product/service quality; productivity; cost of scrap and rework as a percentage of sales; delivery lead-time of purchased materials to our company; and delivery lead-time of finished products/ services to customer. All questions were measured using seven-point Likert-scale to gauge the level of agreement or disagreement on each instrument. Respondents responded to the items from 1 = "strongly disagree" to 7 = "strongly agree" with each statement in the questionnaire.

\section{SAMPLE AND CONTEXT}

To ensure the correct companies are selected with sufficient sample size, the sample method will depend on the population to be studied (Sekaran 2003). In this case, the population is $\mathrm{E} \& \mathrm{E}$ manufacturers with operational records, which is a small population of less than 400 identified companies. The method to determine the minimum sample size is by utilizing G-Power to statistically calculate the required sample based on effect size, error probability and power (Hair et al. 2014; Faul et al. 2007), which yielded 68 as the minimum.

To determine if a sufficient sample response is possible, a list of E\&E manufacturing companies in Malaysia was created from the list of companies in the Federation of Malaysian Manufacturers (2016) directory, and from state investment firms in Malaysia as a validation. The companies were checked with earlier versions of FMM directories to ensure minimum of 5 years operations in Malaysia, and meets the minimum headcount criteria for SME (SME Corporation Malaysia 2012). In view of the pre-determined for the selection of subjects to form the survey sample of this study, a purposive sampling technique was employed. The final list was 350, and as the historical response rate was given as 20-30 percent (Yusr et al. 2017), the decision was to send the survey to $350 \mathrm{E} \& \mathrm{E}$ manufacturer in Malaysia to fulfil study requirements. With follow up reminders performed by phone call, in person visit, and mail, and responses were collected over one quarter.

The request was for respondents who are managing employees and overseeing the operations from all levels of the company in both direct or indirect structures. Therefore, the survey was sent to the top management or management level (such as CEO, Managing Director, General Manager, Department/Division Manager) as the representatives. The respondents requested were to have executive decision-making roles to ensure the familiarity with the concepts and operationalization of Knowledge Management and Agility practices within their respective areas. Respondents were specifically limited to one from each company or independent subsidiary entity of a company, by only sending one questionnaire to each, and only requesting one copy be returned in a single prestamped envelope.

From this sample, a total of 87 valid and completed responses were received within the stipulated time period, corresponding with 24.9 per cent response rate. This is broadly in line with $20-30$ per cent as received by other contemporary research conducted amongst manufacturing firms in Malaysia (Yusr et al. 2017), and better than a general survey of multiple firm types 
in Malaysia (Wong, Tseng \& Tan 2014). In this study, the sample required is less than the collected response, which will provide the model with sufficient power of analyzed results to draw valid conclusions, and thus, the responses received are sufficient to perform model analysis by PLS-SEM.

\section{FINDINGS}

\section{DEMOGRAPHIC BREAKDOWN OF RESPONDENTS}

The responses were assessed for a demographic frequency to provide a context for the results which may offer additional insight not fully captured directly measured items. The ratio of female to male respondents is 51.7 per cent to 48.3 per cent, which is interesting, as this implies that the balance of the workforce in Malaysia is very nearly equal in terms of gender. An alternative explanation is that women are more responsive to needs within the organization and without, and may include survey responses as part of their area of concern. This is supported in literature where women increase organizational conscientiousness (Huse \& Solberg 2006), corporate social responsibility (Bear et al. 2010), and social cooperation (Konrad et al. 2008). While these factors do not lead directly to increased firm performance (Carter et al. 2010), the characteristics of preparedness and conscientiousness (Huse \& Solberg 2006) supports the factor of knowledge management practices.

The second factor of education resulted in more than 80 per cent with university degrees, and with more than 30 per cent holding advanced degrees. The focus on higher education by the Government from earlier Malaysia Plan (Rancangan Malaysia Ke-Sebelas 2016) through to the latest revision, where the goal is developing skilled workers and professionals, has brought a boom in educational attainment at all levels of society. This effect is also seen in the years of experience, where almost 50 per cent have accumulated five years or less of experience, yet are in managerial type roles, which is another goal of the Malaysian Government.

The companies in the study are from different regions of the world, with the US leading as the most substantial individual country foreign direct investment (FDI) source. At the same time, Asia contributes the most FDI by region. Companies with origins in Malaysia lead with 44.8 per cent, which has not changed significantly since an earlier study in the same industry ( $\mathrm{Ng} \&$ Jantan 2010). The companies are also on average more than ten years in operation, with more than 65 per cent classified as large companies. A point to note here is that this imbalance underscores the identified need in the Malaysia Plan (Rancangan Malaysia Ke-Sebelas 2016) for developing new small and medium enterprises (SMEs) to drive local productivity.
TABLE 1. Demographic statistics of participating companies and respondents

\begin{tabular}{|c|c|c|c|}
\hline & & Frequency & $\begin{array}{l}\text { Per cent } \\
(\%)\end{array}$ \\
\hline $\begin{array}{l}\text { Demograph } \\
\text { Companies }\end{array}$ & cs of Participating & & \\
\hline Company & Europe & 7 & 8.0 \\
\hline Origin & USA & 18 & 20.7 \\
\hline & Asia & 23 & 26.5 \\
\hline & Local & 39 & 44.8 \\
\hline Years & $<10$ Years & 10 & 11.5 \\
\hline Established & $>10$ Years & 77 & 88.5 \\
\hline Number of & $<200$ employees & 30 & 34.5 \\
\hline Employees & >200 employees & 57 & 65.5 \\
\hline Demograph & cs of Respondents & & \\
\hline Gender & Female & 45 & 51.7 \\
\hline & Male & 42 & 48.3 \\
\hline Education & High School & 1 & 1.1 \\
\hline & Certificate / Diploma & 14 & 16.1 \\
\hline & Advanced Diploma & 1 & 1.1 \\
\hline & Bachelor's Degree & 42 & 48.3 \\
\hline & Master's Degree & 25 & 28.7 \\
\hline & $\begin{array}{l}\text { PHD / Doctorate } \\
\text { Degree }\end{array}$ & 4 & 4.6 \\
\hline Experience & $<1$ Year & 6 & 6.9 \\
\hline & $>1$ Year & 30 & 34.5 \\
\hline & $>5$ Years & 19 & 21.8 \\
\hline & $>10$ Years & 32 & 36.8 \\
\hline
\end{tabular}

\section{MEASUREMENT MODEL ASSESSMENT}

The method for assessment of the model was by Structural Equation Modelling with Partial Least Square (PLS) using the Smart PLS3 software. This allows for relationships between the factors to be analyzed all at the same time to minimize processing errors and allows a single calculated score where all factor considerations are present.

The completed response data were tested for common method bias, Skewness, and Kurtosis to ensure responses are valid. The assessment for common method bias (CMB) using Harman's single factor test to reduce the risk of inflated relationships caused by the measurement method, rather than to the constructs, which would otherwise invalidate the model results (Podsakoff \& Organ 1986). The results showed that the sum of squared loading per cent of Variance totalled 29.8 per cent, demonstrating that $\mathrm{CMB}$ is not a concern in this study (Podsakoff et al. 2003). 
TABLE 2. Common method bias

\begin{tabular}{|c|c|c|c|c|c|c|}
\hline \multirow{2}{*}{$\begin{array}{l}\text { Harman's Single } \\
\text { Factor Test }\end{array}$} & \multicolumn{3}{|c|}{ Initial Eigenvalues } & \multicolumn{3}{|c|}{ Extraction Sums of Squared Loadings } \\
\hline & Total & $\begin{array}{l}\text { Percentage of } \\
\text { Variance }\end{array}$ & $\begin{array}{c}\text { Cumulative } \\
\text { Percentage (\%) }\end{array}$ & Total & $\begin{array}{l}\text { Percentage of } \\
\text { Variance }\end{array}$ & $\begin{array}{c}\text { Cumulative } \\
\text { Percentage (\%) }\end{array}$ \\
\hline 1 & 18.257 & 30.944 & 30.944 & 17.592 & 29.817 & 29.817 \\
\hline 2 & 3.918 & 6.641 & 37.586 & & & \\
\hline 3 & 2.891 & 4.899 & 42.485 & & & \\
\hline 4 & 2.778 & 4.709 & 47.194 & & & \\
\hline 5 & 2.275 & 3.856 & 51.050 & & & \\
\hline 6 & 2.101 & 3.562 & 54.612 & & & \\
\hline 7 & 1.931 & 3.273 & 57.885 & & & \\
\hline
\end{tabular}

TABLE 3. Variance important factor, skewness and kurtosis of constructs

\begin{tabular}{|c|c|c|c|c|c|c|}
\hline \multirow{2}{*}{\multicolumn{2}{|c|}{ Construct }} & \multicolumn{3}{|c|}{ Variance Important Factor (VIF) } & \multirow[t]{2}{*}{ Skewness } & \multirow[t]{2}{*}{ Kurtosis } \\
\hline & & 1 & 2 & 3 & & \\
\hline 1 & Agility & a & & & -0.177 & -0.9 \\
\hline 2 & Firm Performance & 2.254 & a & & -0.410 & -0.34 \\
\hline 3 & Knowledge Management Practices & 1.000 & 2.254 & a & -0.192 & -0.72 \\
\hline
\end{tabular}

Note: $\mathrm{a}=$ not valid

TABLE 4. Reliability and discriminant validity of constructs

\begin{tabular}{|c|c|c|c|c|c|c|c|c|}
\hline \multirow[b]{2}{*}{ Construct } & \multirow[b]{2}{*}{ Indicator } & \multirow[b]{2}{*}{ Outer Loading } & \multicolumn{3}{|c|}{ Reliability \& Validity } & \multicolumn{3}{|c|}{ HTMT } \\
\hline & & & $\begin{array}{l}\text { Average Variance } \\
\text { Extracted (AVE) }\end{array}$ & $\begin{array}{l}\text { Composite } \\
\text { Reliability }\end{array}$ & $\begin{array}{c}\text { Cronbach's } \\
\text { Alpha }\end{array}$ & AGL & $\mathrm{FP}$ & KMP \\
\hline Agility (AGL) & $\begin{array}{c}\text { AGL1 } \\
\text { AGL3 } \\
\text { AGL4 } \\
\text { AGL5 } \\
\text { AGL6 } \\
\text { AGL7 } \\
\text { AGL8 } \\
\text { AGL9 } \\
\text { AGL10 }\end{array}$ & $\begin{array}{l}0.656 \\
0.813 \\
0.765 \\
0.737 \\
0.738 \\
0.670 \\
0.761 \\
0.642 \\
0.763\end{array}$ & 0.532 & 0.911 & 0.889 & $\mathrm{a}$ & & \\
\hline $\begin{array}{l}\text { Firm Performance } \\
\text { (FP) }\end{array}$ & $\begin{array}{l}\text { FP1 } \\
\text { FP2 } \\
\text { FP4 } \\
\text { FP5 }\end{array}$ & $\begin{array}{l}0.745 \\
0.892 \\
0.803 \\
0.769\end{array}$ & 0.647 & 0.879 & 0.816 & 0.482 & $\mathrm{a}$ & \\
\hline $\begin{array}{c}\text { Knowledge } \\
\text { Management } \\
\text { Practices (KMP) }\end{array}$ & $\begin{array}{c}\text { KM3 } \\
\text { KM4 } \\
\text { KM5 } \\
\text { KM6 } \\
\text { KM7 } \\
\text { KM8 } \\
\text { KM9 } \\
\text { KM10 } \\
\text { KM11 } \\
\text { KM12 }\end{array}$ & $\begin{array}{l}0.686 \\
0.751 \\
0.616 \\
0.779 \\
0.649 \\
0.751 \\
0.655 \\
0.756 \\
0.690 \\
0.779 \\
\end{array}$ & 0.509 & 0.912 & 0.892 & 0.823 & 0.577 & a \\
\hline
\end{tabular}

Note: $\mathrm{a}=$ Not valid

KMP denotes knowledge management practices; AGL denotes agility; FP denotes firm performance 
The Skewness and Kurtosis were within the limits as suggested by Kline (2011), where values of Skewness between $+/-3$ and Kurtosis between $+/-7$ indicate that there are no significant extremes in the data. Similarly, the Variance Important Factor (VIF) collinearity values are less than a value of 5 , showing no inflation of factor correlation issues (Hair et al. 2014).

\section{INDICATOR LOADINGS}

In the test for Indicator's loadings, literature suggests that a value above 0.6 is required (Chin, Peterson \& Brown 2008). This is supported in PLS-SEM guidance literature where the decision for value ranges is established (Hair et al., 2014). Values of loadings $<0.4$ are removed, values $>0.7$ accepted, and values between 0.4-0.7 are analysed for effect on AVE and CR, and are accepted if measures are not increased above threshold. The results for the PLS-SEM path analysis collected in Table 4, showed one each indicator from Agility and Firm Performance, and 2 indicators from Knowledge Management Practice were below the 0.6 threshold and were removed (Chin et al. 2008).

The next assessment was carried out to test the reliability and validity of the model. The results show that the reliability is not a concern, with Cronbach's Alpha (Within range of 0.7-0.9), Composite Reliability $(>0.7)$ and Average Variance Extracted (AVE of $>0.5$ ) are all within the acceptable range (Hair et al. 2014).

The second test is for the discriminant validity of the constructs to ensure that the measures are empirically unique and not replicated by other measures. The method used is the Heterotrait-Monotrait Ratio of correlations (HTMT) as the recommended practice (Henseler et al. 2015). HTMT is an estimate of the correlation between the constructs in the model, which is the average of the heterotrait-heteromethod correlations of indicators across constructs measuring different phenomena (Henseler et al. 2015). Values below 0.85 are acceptable and indicate there is discriminant validity, i.e., no relationship has been found between the constructs (Kline 2011). The results for HTMT ratio between all constructs are all within acceptable limits of $<0.85$, and that discriminant validity between constructs has been demonstrated.

\section{STRUCTURAL MODEL ASSESSMENT}

The finding of the model provides a clearer understanding of the direct relationships of the factors of agility and knowledge management practices on firm performance and the overall indirect relationship of the model.

In the test of the first hypothesis, agility is shown to lack a direct relationship with Firm Performance measures, in contrary to much literature showing positive correlation of the factors (Inman et al. 2011; Swafford et al. 2008). The study by Gligor et al. (2015) provides illumination in this regard, as the measures of firm performance which include measures of financial performance have previously been found to lack a direct correlation. The findings in this study are in line with the previous study and show that a secondary factor relationship exists between agility and firm performance. Thus, $\mathrm{H}_{1}$ is not supported.

The test for the second relationship between agility and knowledge management practices shows a very strong relationship ( $\boldsymbol{\beta}$-value of $0.746, p<0.01)$. The data indicated that agility is strongly related to Knowledge Management Practices directly, and Here, $\mathrm{H}_{2}$ is strongly supported.

The test of knowledge management practices in relationship with firm performance was demonstrated to be positive with $(\boldsymbol{\beta}$-value of $0.437, p<0.05)$. The findings were in line with Zack et al. (2009), which showed the direct relationship of knowledge management practices with positive firm performance is a given in organizational context. Knowledge in the context of high technology manufacturing is viewed as a resource of the firm, and enabler of other factors which leads to

TABLE 5. Results of the direct relationships

\begin{tabular}{cccccccccc}
\hline Hypothesis & Direct Path & Std $\boldsymbol{\beta}$-value & SE & $t$-value $(\geq 1.96)$ & Decision & LL (2.5) & UL (97.5) & $\mathrm{F}^{2}$ & VIF \\
\hline 1 & AGL -> FP & 0.094 & 0.150 & 0.627 & Not Supported & -0.234 & 0.352 & 0.005 & 2.254 \\
2 & AGL -> KMP & 0.746 & 0.057 & $* * 13.058$ & Supported & 0.629 & 0.853 & 1.254 & 1.000 \\
3 & KMP -> FP & 0.437 & 0.135 & $* * 3.245$ & Supported & 0.188 & 0.737 & 0.114 & 2.254 \\
\hline
\end{tabular}

Two tailed; ${ }^{*} \mathrm{p}<0.05(\mathrm{t}>1.96) ; * * \mathrm{p}<0.01(\mathrm{t}>2.58)$

Note: $\mathrm{LL}=$ Lower Limit, UL=Upper Limit

KMP denotes knowledge management practices; AGL denotes agility; FP denotes firm performance

TABLE 6. Results of the indirect relationships

\begin{tabular}{cccccccc}
\hline Hypothesis & Indirect Path & Std $\boldsymbol{\beta}$-value & SE & $t$-value $(\geq 1.96)$ & Decision & LL (2.5) & UL (97.5) \\
\hline 4 & AGL -> KMP -> FP & 0.326 & 0.111 & $* * 2.945$ & Supported & 0.143 & 0.593 \\
\hline
\end{tabular}

Two tailed; $* \mathrm{p}<0.05(\mathrm{t}>1.96) ; * * \mathrm{p}<0.01(\mathrm{t}>2.58)$

Note: $\mathrm{LL}=$ Lower Limit, UL=Upper Limit

KMP denotes knowledge management practices; AGL denotes agility; FP denotes firm performance 
the increased organizational performance. A secondary factor being that a significant $>50 \%$ of respondents being women may increase the importance of knowledge management practices due to the nature of women who characteristically take their roles seriously, and prepare more conscientiously for meetings (Huse \& Solberg 2006). Thus, the findings support $\mathrm{H}_{3}$.

The fourth test showed that agility is mediated by knowledge management practices in relation to firm performance $(\boldsymbol{\beta}$-value of $0.326, p<0.05)$. This is supported by the RBV related Knowledge-Based View of the firm, which was discussed as the missing factor in the findings with Firm Performance in the study by Gligor et al. (2015). Knowledge management practices is demonstrably the link which enables the agility to be related to a key measure of firm performance, including financial measures, which were previously found to be insignificant. Thus, $\mathrm{H}_{4}$ is supported.

\section{DISCUSSION}

Agility as the ability of responsiveness and flexibility, has been looked into in many fields of research, either in direct or indirect relationships. In most of the domains, agility has demonstrated positive relationships, but there were contrarian findings in particular studies of firm performance. By looking into a secondary factor of Knowledge Management Practices, and how this is practiced in E\&E manufacturing firms in the context of Malaysia, we have gained illumination into the importance of the factors, and can conclusively state that agility, when mediated by Knowledge Management Practices, leads to increased organizational performance. This relationship empirically validates the model of Operational Excellence, where Knowledge Management and Agility are two factors which lead to improved firm performance (Carvalho et al. 2019), which is aimed to spur firms to increase implementation efforts.

In this study, a contrary finding to literature was the strong direct relationship of KMP with FP. In literature, Darroch (2003) has shown that direct relationships of Knowledge Management components have not been related to firm performance measures, except in limited circumstance (Darroch 2005). The view of a weak to no relationship persisted, and even though some studies have found correlation between the practice of knowledge sharing with firm performance (Almahamid et al. 2010), this earlier finding (Darroch 2003; Darroch \& McNaughton 2003) was taken up in the study by Yusr et al. (2017), which cited this lack of relationship, and did not utilize firm performance as a direct outcome. Contrary to that prevailing view, Zack et al. (2009) had clearly stated that individual components do not have strong relationships with firm performance directly due to the actual practices in firms which use all components in a KM system. Thus, the empirical results of the positive relationship of KMP with FP in this study, has clearly demonstrated that Knowledge Management in practice is a fully viable and valid variable in future firm performance studies.

The findings further empirically strengthen the projection of two studies discussed in literature. The first is the study by Inman et al. (2011) where Agility as implemented in a firm, is supported by secondary factor such as knowledge. The second was the study by Gligor et al. (2015), who strongly indicated that an influencing factor was enabling the observed firm performance. This relationship of Agility with Knowledge Management showed clearly the strong positive influence of stored firm knowledge capabilities on operational activities. What was surprising was the strength of the relationship of Agility and Knowledge Management (T-value = 13.058) which was suggested by Carvalho et al. (2019) as interrelated enablers. It is clear that the interrelationship of action as represented by Agility is tied very strongly with resources, as represented by Knowledge Management Practices. Therefore, future studies of firm performance would need to re-assess the direct value of models which only utilize one of the other of the two factors.

The findings have shed light on a key growth region of the world and increased practitioners' insight into how agility can be best harnessed in today's' high technology manufacturing environment. The recommendations from this study findings are discussed in the implications for managers and for theory contribution.

\section{IMPLICATIONS FOR MANAGERS}

From the responses received, the view of both KMP and Agility having been implemented in E\&E manufacturing firms in Malaysia was clearly shown. The uncertainty however was the importance of one factor over the other in priority for the firms in the study, which is a normal managerial consideration for prioritization of implementation. The findings in this study however, have shown that implementing only one of the factors without the synergy of the second factor, leads to less than optimum results. Managers are strongly encouraged to assess the level of implementation for both factors within the organization rather than prioritizing one over the other.

More critical than just the presence of both factors, is the actual practice of utilizing both factors in synergy within all firm operations. The demographics of the respondents may provide an indication of the strong correlation of Agility and Knowledge Management Practice, with the length of employment giving context to the findings. Knowledge Management Practice as a resource, is a result of actions and learning from a firm's history (Gold et al. 2001; Nonaka et al. 1996), which was previously collected by the now more senior employees. Longer term employees who were primarily responsible for earlier knowledge creation and storage $(>10$ years employment in the firm), and newer employees who would need to access stored knowledge to support 
ongoing firm activity $(1<5$ years employment), were the primary respondents in this study with $36.8 \%$ and $34.5 \%$ of respective respondents. In comparison are those between 5-10 years of employment with the firm, who are typically employees with sufficient experience and familiarity with operations, who do not require frequent access to stored knowledge resources.

This finding would indicate the strong relationship of Agility with Knowledge Management Practice could be contextualized to the respondent's employment length, implying the influence of knowledge transfer value on employment progress. Managers are advised to increase policies and utilization efforts of knowledge management practices amongst senior and junior employees to increase the usage from stored knowledge resources for the benefit to the firm's performance.

\section{IMPLICATIONS TO ACADEMIC}

Literature of the Knowledge Based View (KBV) of the firm as the prime mechanism for knowledge resource as a firm advantage, where the primary differentiator between successful multi-national firms and the wider body of smaller firms has been well established (Darroch 2003; Kogut \& Zander 1992; Yusr et al. 2017). However, a growing body of understanding for the correlations which enable the utilization of said knowledge resources to benefit the firm (Carvalho et al. 2019; Gligor et al. 2015; Zack et al. 2009) have indicated the presence of secondary variables, which in this study was clearly demonstrated to be Agility. The findings of exceptionally strong relationship between Knowledge Management Practices with Agility, also implies that knowledge resources could be related in potentially non-linear fashion with other factors, which was not explored in KBV literature. This finding may indicate that knowledge management practices and even the components of Knowledge Management could function as a moderator in more relationships, which would open exploration for non-linear effects of knowledge resource on Firm Performance.

This study adds to the growing literature of secondary factors for correlation with actual firm performance advantage, which future KBV studies can draw form to expand the value of the knowledge resources. Future studies of factors linked to both Knowledge Management and Firm Performance can draw upon the strong relationship offered above to test social and cultural factors which were previously explained in KBV but were not part of the formation of the original theory (Kogut \& Zander 1992).

\section{LIMITATIONS}

While the results are strongly positive, certain limitations of the study exist, which are that while the research is useful as supporting data in decision making, the study is limited to Malaysian E\&E manufacturers, requires additional studies in the context of other nations and industries before generalizability. Also, as the study was cross-sectional, the varying importance based on long term operations, with external cyclical and non-cyclical business environment influence, needs to be considered before future studies and practitioner implementation can be conclusively made.

\section{CONCLUSION}

The study has demonstrated the relationship between agility, knowledge management practices, and Firm Performance, in the context of E\&E manufacturing firms in Malaysia. Knowledge management practices is found to have a strong relationship with agility and mediate the association of agility with firm performance. The findings results can enhance efforts by policy-makers, who are presently in the process of formulating strategies to build up human capital and develop local firms to achieve world-class performance. Private firms who are looking for enhancements to the existing operations can utilize the findings to focus efforts in the area to maximize the returns on investment. Finally, the results should act as a catalyst for further research in the field of agility and knowledge management, particularly in other contexts not yet explored.

\section{ACKNOWLEDGEMENT}

This study was part of research funded under the Bridging Grant Scheme (304.PPAMC.6316308) which is supported by the Universiti Sains Malaysia.

\section{REFERENCES}

Ahire, S.L., Golhar, D.Y. \& Waller, M.A. 1996. Development and validation of TQM implementation constructs. Decision Sciences 27(1): 23-56.

Ahire, S.L. \& O' shaughnessy, K.C. 1998. The role of top management commitment in quality management: an empirical analysis of the auto parts industry. International Journal of Quality Science 3(1): 5-37.

Almahamid, S., Awwad, A. \& McAdams, A.C. 2010. Effects of organizational agility and Knowledge sharing on competitive advantage: an empirical study in Jordan. International Journal of Management 27(3): 387.

Bakar, L.J.A. \& Ahmad, H. 2010. Assessing the relationship between firm resources and product innovation performance: A resource-based view. Business Process Management Journal 16(3): 420-435.

Barney, J. 1991. Firm resources and sustained competitive advantage. Journal of Management 17(1): 99-120.

Bear, S., Rahman, N., \& Post, C. 2010. The impact of board diversity and gender composition on corporate social responsibility and firm reputation. Journal of Business Ethics 97(2): 207-221.

Bell DeTienne, K., Dyer, G., Hoopes, C. \& Harris, S. 2004. Toward a model of effective knowledge management and 
directions for future research: Culture, leadership, and CKOs. Journal of Leadership \& Organisational Studies 10(4): 26-43.

Buenechea-Elberdin, M., Sáenz, J. \& Kianto, A. 2017. Exploring the role of human capital, renewal capital and entrepreneurial capital in innovation performance in high-tech and low-tech firms. Knowledge Management Research \& Practices 15(3): 369-379.

Carter, D.A., D'Souza, F., Simkins, B.J. \& Simpson, W.G. 2010. The gender and ethnic diversity of US boards and board committees and firm financial performance. Corporate Governance: An International Review 18(5): 396-414.

Carvalho, A.M., Sampaio, P., Rebentisch, E., Carvalho, J.Á. \& Saraiva, P. 2019. Operational excellence, organizational culture and agility: The missing link? Total Quality Management \& Business Excellence 30: 13-14, 14951514.

Carvalho, H., Azevedo, S.G. \& Cruz-Machado, V. 2012. Agile and resilient approaches to supply chain management: influence on performance and competitiveness. Logistics Research 4(1-2): 49-62.

Cavusgil, S.T. \& Knight, G. 2015. The born global firm: An entrepreneurial and capabilities perspective on early and rapid internationalization. Journal of International Business Studies 46(1): 3-16.

Cegarra-Navarro, J.G., Soto-Acosta, P. \& Wensley, A.K. 2016. Structured knowledge processes and firm performance: The role of organizational agility. Journal of Business Research 69(5): 1544-1549.

Chin, W.W., Peterson, R.A. \& Brown, S. P. 2008. Structural equation modeling in marketing: Some practical reminders. Journal of Marketing Theory and Practice 16(4): 287-298.

Darroch, J. 2003. Developing a measure of knowledge management behaviours and practices. Journal of Knowledge Management 7(5): 41-54.

Darroch, J. 2005. Knowledge management, innovation and firm performance. Journal of Knowledge Management 9(3): 101-115.

Darroch, J. \& McNaughton, R. 2003. Beyond market orientation: Knowledge management and the innovativeness of New Zealand firms. European journal of Marketing 37(3/4): 572-593.

Davenport, T.H. 1996. Some principles of knowledge management. Strategy \& Business 1(2): 34-40.

Davenport, T.H. \& Klahr, P. 1998. Managing customer support knowledge. California Management Review 40(3): 195208.

Davenport, T. H., \& Prusak, L. 1998. Working Knowledge: How Organizations Manage What They Know. Boston: Harvard Business Press.

Dow, D., Samson, D., \& Ford, S. 1999. Exploding the myth: do all quality management practices contribute to superior quality performance? Production and Operations Management 8(1): 1-27.

Dubey, R. \& Gunasekaran, A. 2015. Exploring soft TQM dimensions and their impact on firm performance: some exploratory empirical results. International Journal of Production Research 53(2): 371-382.

Dun \& Bradstreet 2020. Business Impact of the Coronavirus. Available at https://www.dnb.com/perspectives/ supplychain/wuhan-coronavirus-business-impact.html

Faul, F., Erdfelder, E., Lang, A.-G. \& Buchner, A. 2007. G*Power 3: A flexible statistical power analysis program for the social, behavioral, and biomedical sciences. Behavior Research Methods 39: 175-191.

FMM. 2016. Federation of Malaysian manufacturers publication. Available at http://www.fmm.org.my/ Publications-@-Publications_List.aspx

Gligor, D.M., Esmark, C.L. \& Holcomb, M.C. 2015. Performance outcomes of supply chain agility: When should you be agile? Journal of Operations Management 33: 71-82.

Gligor, D.M. \& Holcomb, M.C. 2012. Antecedents and consequences of supply chain agility: Establishing the link to firm performance. Journal of Business Logistics 33(4): 295-308.

Gold, A.H., Malhotra, A. \& Segars, A.H. 2001. Knowledge management: an organizational capabilities perspective. Journal of Management Information Systems 18(1): 185214.

Grant, R. M. 1996. Toward a knowledge-based theory of the firm. Strategic Management Journal 17(S2): 109-122.

Gunasekaran, A. 1998. Agile manufacturing: Enablers and an implementation framework. International Journal of Production Research 36(5): 1223-1247.

Hair Jr, J.F., Hult, G.T.M., Ringle, C.M. \& Sarstedt, M. 2014. A Primer on Partial Least Squares Structural Equation Modeling (PLS-SEM). Los Angeles, CA: Sage Publications.

Hamzah, N.A. \& Woods, P. 2004. Knowledge management framework for Malaysian small and medium size enterprises (SMEs). In Proceedings of the Knowledge Management International Conference and Exhibition 2004, 14-15 February. Universiti Utara Malaysia, Sintok, Malaysia.

Harbour, J.L. 2009. The Basics of Performance Measurement. CRC Press.

Henseler, J., Ringle, C.M. \& Sarstedt, M. 2015. A new criterion for assessing discriminant validity in variance-based structural equation modeling. Journal of the Academy of Marketing Science 43(1): 115-135.

Huang, C.C. 2009. Knowledge sharing and group cohesiveness on performance: An empirical study of technology R\&D teams in Taiwan. Technovation 29(11): 786-797.

Huse, M. \& Grethe Solberg, A. 2006. Gender-related boardroom dynamics: How Scandinavian women make and can make contributions on corporate boards. Women in Management Review 21(2): 113-130.

Hussinki, H., Kianto, A., Vanhala, M. \& Ritala, P. 2017. Assessing the universality of knowledge management practices. Journal of Knowledge Management 21(6): 1596-1621.

International Labor Organization. 2014. Ups and downs in the electronics industry: Fluctuating production and the use of temporary and other forms of employment. Available at https://www.ilo.org/sector/Resources/ publications/ WCMS_317267/lang--en/index.htm

Inman, R.A., Sale, R.S., Green, K.W. \& Whitten, D. 2011. Agile manufacturing: relation to JIT, operational performance and firm performance. Journal of Operations Management 29(4): 343-355.

Janipha, N.A.I. \& Ismail, F. 2013. Conceptualization of quality issues in Malaysian construction environment. ProcediaSocial and Behavioral Sciences 101: 53-61.

Kaynak, H. 2003. The relationship between total quality management practices and their effects on firm performance. Journal of Operations Management 21(4): $405-435$ 
Khalifa, M., Yan Yu, A. \& Ning Shen, K. 2008. Knowledge management systems success: A contingency perspective. Journal of Knowledge Management 12(1): 119-132.

Kline, R.B. 2011. Principles and Practices of Structural Equation Modeling. 3rd Edition. Guilford Publications.

Knight, T. \& Howes, T. 2003. Knowledge Management: A Blueprint for Delivery: A Programme for Mobilizing Knowledge and Building the Learning Organization. Routledge.

Kogut, B. \& Zander, U. 1992. Knowledge of the firm, combinative capabilities, and the replication of technology. Organization Science 3(3): 383-397.

Konrad, A.M., Kramer, V. \& Erkut, S. 2008. The impact of three or more women on corporate boards. Organisational Dynamics 37(2): 145-164.

Ling, T.N. \& Shan, L.Y. 2010. Knowledge management adoption among Malaysia's SMEs: Critical factors. 5th International Conference "Knowledge Management: Theory, Research and Practice, 12-13 November. "Carol I" National Defense University, Romania.

Mehralian, G., Nazari, J.A. \& Ghasemzadeh, P. 2018. The effects of knowledge creation process on organizational performance using the BSC approach: The mediating role of intellectual capital. Journal of Knowledge Management 22(4): 802-823.

Nanni, A.J., Dixon, J.R. \& Vollmann, T.E. 1992. Integrated performance measurement: management accounting to support the new manufacturing realities. Journal of Management Accounting Research 4(1): 1-19.

Ng, K.S. \& Jantan, M. 2010. Quality management practices in Malaysia: Perceived advancement in quality management and business performance. In 2010 IEEE International Conference on Management of Innovation \& Technology, 2-5 June. Singapore.

Nonaka, L., Takeuchi, H. \& Umemoto, K. 1996. A theory of organizational knowledge creation. International Journal of Technology Management 11(7-8): 833-845.

Nonaka, I. \& Von Krogh, G. 2009. Perspective-Tacit knowledge and knowledge conversion: Controversy and advancement in organizational knowledge creation theory. Organization Science 20(3): 635-652.

Ong, E.C., Tan, C.L. \& Amran, A. 2019. The key is ownership of agility. Strategic Direction 5(1): 9-12.

Özer, A.C. 2020. The Effect of the US-China Trade War on Global Trade. In International Trade Policies in the Era of Globalisation, 56-70. IGI Global.

Podsakoff, P.M., MacKenzie, S.B., Lee, J.Y. \& Podsakoff, N.P. 2003. Common method biases in behavioral research: A critical review of the literature and recommended remedies. Journal of Applied Psychology 88(5): 879.

Podsakoff, P.M. \& Organ, D.W. 1986. Self-reports in organizational research: Problems and prospects. Journal of Management 12(4): 531-544.

Rahman, S. \& Bullock, P. 2002. Relationships between soft TQM, hard TQM, and organizational performance. The International Journal of Management Sciences 33: 73-83.

Rancangan Malaysia Ke-Sebelas 2016-2020. 2016. Available at http://www.epu.gov.my/en/rmk/eleventh-malaysiaplan-2016-2020

Reichhart, A. \& Holweg, M. 2007. Creating the customerresponsive supply chain: a reconciliation of concepts. International Journal of Operations \& Production Management 27(11): 1144-1172.
Samson, D. \& Terziovski, M. 1999. The relationship between TQM practices \& operational performances. Journal of Operation Management 17: 393-409.

Sekaran, U. 2003. Research Methods for Business: A Skill Building Approach. New York: John Wiley \& Sons.

Sharifi, H. \& Zhang, Z. 2001. Agile manufacturing in practices - Application of a methodology. International Journal of Operations \& Production Management 21(5/6): 772-794.

Shipham, S. 2011. The MBA research process: Establishing a business case-a business research imperative. Management Today 29(4): 60-63.

SME Corporation Malaysia. 2012. SME Master Plan 2012 -2020. Kuala Lumpur. Available at https://www. smecorp. gov.my/images/Publication/sme-masterplan/smemasterplan-eng.pdf

Swafford, P.M., Ghosh, S. \& Murthy, N. 2008. Achieving supply chain agility through IT integration and flexibility. International Journal of Production Economics 116(2): 288-297.

Tan, L.P. \& Wong, K.Y. 2015. Linkage between knowledge management and manufacturing performance: A structural equation modeling approach. Journal of Knowledge Management 19(4): 814-835.

Tan, C.L., Yeo, S.F. \& Low, C.H. 2018. Green supply chain management practices and organizational performance: An empirical study in Malaysian manufacturing firms. Jurnal Pengurusan 52(2018): 19-32.

Theriou, N., Maditinos, D. \& Theriou, G. 2011. Knowledge management enabler factors and firm performance: An empirical research of the Greek medium and large firms. European Research Studies 14(2): 97.

Wernerfelt, B. 1984. A resource-based view of the firm. Strategic Management Journal 5(2): 171-180.

Wiig, K.M. 1997. Knowledge management: Where did it come from and where will it go?. Expert Systems with Applications 13(1): 1-14.

Wong, W.P., Tseng, M.L. \& Tan, K.H. 2014. A business process management capabilities perspective on organization performance. Total Quality Management \& Business Excellence 25(5-6): 602-617.

World Bank Group. 2016. Malaysia Economic Monitor, December 2016: The Quest for Productivity Growth. World Bank. Available at http://pubdocs.worldbank. org/en/183141482112459157/MEM-ProductivityPresentation-December-19.pdf

World Health Organization. 2020. Coronavirus disease 2019 (COVID-19) Situation Report - 29. Available at https:// www.who.int/docs/default-source/coronaviruse/situationreports/20200218-sitrep-29-covid-19.pdf

Yauch, C.A. 2011. Measuring agility as a performance outcome. Journal of Manufacturing Technology Management 22(3): 384-404.

Yee, Y.M., Tan, C.L. \& Ramayah, T. 2019. Back to basics: building a knowledge management system. Strategic Direction 35(2): 1-3.

Yee, Y.M., Tan, C.L., Nasurdin, A.M., Yeo, S.F. \& Ramayah, T. 2020. Building a knowledge-intensive medical device industry: The effect of knowledge creation in $\mathrm{R} \& \mathrm{D}$ project performance. Jurnal Pengurusan 58(2020): 119-131.

Youssef, M.A. 1994. Design for manufacturability and timeto-market, part 1: Theoretical foundations. International Journal of Operations \& Production Management 14(12): 6-21. 
Yusr, M.M., Mokhtar, S.S.M., Othman, A.R. \& Sulaiman, Y. 2017. Does interaction between TQM practices and knowledge management processes enhance the innovation performance? International Journal of Quality \& Reliability Management 34(7): 955-974.

Yusuf, Y.Y., Sarhadi, M. \& Gunasekaran, A. 1999. Agile manufacturing: The drivers, concepts and attributes. International Journal of Production Economics 62(1): 33-43.

Zack, M., McKeen, J. \& Singh, S. 2009. Knowledge management and organizational performance: an exploratory analysis. Journal of Knowledge Management 13(6): 392-409.

Zhang, Q., Vonderembse, M.A. \& Lim, J.S. 2003. Manufacturing flexibility: Defining and analyzing relationships among competence, capability, and customer satisfaction. Journal of Operations Management 21(2): 173-191.

Zhang, D.Z. 2011. Towards theory building in agile manufacturing strategies - Case studies of an agility taxonomy. International Journal of Production Economics 131(1): 303-312.
Zhang, Z. \& Sharifi, H. 2000. A methodology for achieving agility in manufacturing organisations. International Journal of Operations \& Production Management 20(4): 496-513.

Zhang, Z. \& Sharifi, H. 2007. Towards theory building in agile manufacturing strategy-A taxonomical approach. IEEE Transactions on Engineering Management 54(2): 351370.

\section{Eu Chin Ong}

Graduate School of Business

Universiti Sains Malaysia

11800 USM Pulau Pinang, Malaysia

E-Mail: ongeuchin.usm@gmail.com

Cheng Ling Tan (corresponding author)

Graduate School of Business

Universiti Sains Malaysia

11800 USM Pulau Pinang, Malaysia

E-Mail: tanchengling@usm.my 